\title{
Economic Growth Path of EU Countries and Turkey under the Consideration of E-commerce Market
}

\author{
Ahmet Salih İKİZ \\ Muğla Sitkı Koçman Üniversitesi \\ Turkey
}

\begin{abstract}
With the end of World War II, the Europe region began to focus towards development of the economy. Since then, large scale development of the economy has taken place across Europe with the integration of innovative technological solutions. Today, ecommerce is a budding phenomenon in Europe, showing more promise than most other industries due to its contribution to the region's foreign investment inflows, economic growth and exports. This study examined the contribution of ecommerce market in economic growth of EU-15, EU-27 and Turkey region for the period 2005-2019. The analysis shows the ecommerce market of EU-27 is developed while there is limited usage of the internet and ICT in Turkey, which enhances opportunities for growth in the region.The findings of this study reveal that among the chosen regions i.e. EU-15, EU-27, and Turkey, the positive contribution of ecommerce towards economic growth can be witnessed for EU-27 and Turkey.
\end{abstract}

Keywords: Ecommerce, economic growth, Internet usage, Turkey, Europe.

\section{Introduction}

\subsection{Background of European Union}

The European Union (EU) is a unique economic and political partnership between its member states wherein treaties were signed for promotion of economic and peace-based recovery of Europe ${ }^{1}$. The success of the single community led by 6 countries (Belgium, Germany, France, Italy, Netherlands, and Luxembourg) by end of 1960s led to first enlargement of the Union in 1973 with integration of Denmark, UK, and Ireland. Further, in 1981 Greece joined the community followed by Spain and Portugal in 1986, eventually encompassing 28 countries by 2013. However, in 2019, with exit of UK from EU, the number of member counties reduced back to EU-272.

\subsection{Economic growth of EU-15, EU-27 and Turkey}

With the end of World War II, Western Europe has experienced robust growth in its economy. During this time, the GDP per capita of EU-15 grew more than $70 \%$ that of the US in 1980 as compared to less than $50 \%$ in $1945^{3}$. Intra-EU trade increased since 1992 with a GDP of $14.2 \%$ in 1995 to $20.8 \%$ in 2015 . Mainly this increase could be witnessed before the period of global financial crisis i.e. 2008 wherein after it, the EU exports were around $21 \%$ after 2008. Following the intra EU trade of goods, service trade also increased from 3\% in 1992 to $6.1 \%$ in 2013. Further, the outward FDI flows as \% of EU-wide GDP shows that for EU-15, the FDI increased from 6.9\% in 1994 to $27.6 \%$ in 2002 which increased to $33.6 \%$ in 2005 with EU-25 and 51.6\% with EU-27 in $2012^{4}$. Thus, despite the presence of many political and financial crises, the economy of EU has been growing.

Turkey on the other hand is the political and economic area where the three regions i.e. Europe, Middle East, and former Soviet Union intersect ${ }^{5}$. Since 1994, due to the custom union of EU, political instability, natural disasters, foreign affair problems, and domestic policies, Turkey witnessed three major economic crises. The implementation of various economic programs and improvement in business environment improved its economic growth from approximately $4 \%$ in 2006 to $8.9 \%$ in 2014 but fell to $3.2 \%$ in 2016. Imports have risen in the country, causing the trade balance to deteriorate to USD 55.3 billion in 2018. However, the developed infrastructure and the competitive workforce of Turkey shows substantial scope for improvement in its growth trajectory ${ }^{6}$.

\subsection{E-commerce market of EU-15, EU-27, and Turkey}

Among other factors, ecommerce has contributed immensely to Europe's economic growth, particularly in the retail industry. The industry was unperturbed by the 2008 global economic crisis which crippled almost all of

\footnotetext{
'CSR, 'The European Union: Questions and Answers' (2019).

${ }^{2} \mathrm{CSR}$ (n 1).

${ }^{3}$ Leszek Balcerowicz and others, 'Economic Growth in the European Union' [2013] Lisbon Council E-book 80.

${ }^{4}$ Patrice Muller and others, 'The EU Single Market: Impact on Member States' [2017] LE Europe 4.

${ }^{5}$ Yilmaz Arguden, 'An Overview of the Turkish Economy: Outlook and Current Perspectives' [2007] The Middle East Institute Policy Brief.

${ }^{6}$ Burak Sansal, 'Turkish Economy' (2020) <http://www.allaboutturkey.com/yagligures.htm>. 
world's major economies. Turkey's retail sector generated more than $€ 200$ billion with of sales in $2014^{7}$. On the other hand, the internet penetration rate in Europe increased from $68 \%$ in 2011 to $81 \%$ in 2016, with about $91 \%$ of all Europeans purchasing products online. For the EU-15 region, ecommerce sales increased from $€ 157.01$ billion to $€ 513.259$ billion in 2013-2017, while EU-27 has saw increase from $€ 158.709$ billion to $€ 524.45$ billion during the same period. In Turkey, ecommerce sales increased from $€ 1.07$ billion Euros to $€ 11.17$ billion $^{8}$. Thus, on an average the contribution of ecommerce to GDP is 3.07\% for EU-15, 1.32\% for EU-27 and 2.09\% for Turkey in $2019^{9}$. This indicates that with the increased role of ecommerce in economic growth in the European region, the trade balance is improving.

\section{Aim of the study}

This study aims to examine the contribution of ecommerce in the economic growth of EU-15, EU-27, and Turkey.

\section{Literature Review}

\subsection{Economic status of EU-15, EU-27, and Turkey}

With the occurrence of many economic and political crises, the economy of European Union experienced lower productivity, less human capital, and lower employment. During 1995-2002, the intra EU- exports share in EUwide GDP for EU-15 increased from 14.2\% to $18.1 \%$ which further rose to $21.3 \%$ in 2011 for EU-27.Among the member countries of EU-27 in 2015, the contribution of intra-EU trade of goods in total trade of the country was highest in Slovakia with 70.4\% followed by64.8\% in Czech Republic, 63.7\% in Lithuania and $61.6 \%$ in Hungary. In EU-15 countries, Belgium's intra-EU trade stood at $58 \%$ of its total trade ${ }^{10}$. After the global financial crisis, the economic status of the European Union fell, leading to reduction in the manufacturing output, profits and investment ${ }^{11}$. Contrary to the European Union's trend, Turkey showed strong economic growth albeit with external imbalances. With GDP growth of 5.8\% in 2006, the country focused on using the strongly expansionary monetary policies and creating a way for the emergence of medium sized firms ${ }^{12}$. This business sector modernization fastens pace of development by raising the GDP rate to $7.4 \%$ in 2017 but also raised the trade imbalance ${ }^{13}$. Though this promotion of business sector enabled improvement of labor productivity with many other OECD countries, the lack of labor resource utilization, high inflation rate i.e. $16.3 \%$ in 2018, and continuous rise of unemployment i.e. to $11 \%$ in 2018 constitute towards the imbalance of economy ${ }^{14}$.

\subsection{Contribution of Ecommerce market in Economic Growth}

Electronic commerce or E-commerce refers to the transmission of data or funds through the internet in order to facilitate the sales and purchase of goods and services across the countries. Moving towards the third industrial revolution wherein shift of industries towards the internet is taking place, there has been a rise in the opportunities available in commercial or economic fields. Popular ecommerce companies like Amazon and Alibaba not only reduce the time and effort in sale and delivery of goods to consumers, but also facilitate improvement in economic growth, foreign markets and exports ${ }^{15}$. In the EU, of the 797.14 million population, about $30 \%$ of online shoppers are millennials (belonging to age group 18-34 years), followed by $34 \%$ who belong to Gen X category (35-54 years), while $31 \%$ are Boomers (55-74 years). Denmark which is a part of EU-15 group ranks third globally in the ease of doing business ranking, while EU-27 country Lithuania ranks fourteenth in the world, and Turkey ranks $43^{\text {rd }}$ in the world in $2019^{16}$. The contribution of ecommerce to GDP of the EU-15 stood at $0.13 \%$ while forEU-27 it stood at $0.14 \%$ in $2015^{17}$. Thus, the promotion of ecommerce market in the European economy resulted in improving the economic growth level of the countries.

\footnotetext{
${ }^{7}$ Nestor Duch-Brown and Bertin Martens, 'The European Digital Single Market: Its Role in Economic Activity in the EU', vol 17 (2015) <https://ec.europa.eu/jrc/sites/jrcsh/files/JRC98723.pdf>.

${ }^{8}$ Jorij Abraham and Sara Lone, 'European Ecommerce Report 2017' (2017).

${ }^{9}$ Sara Lone and others, 'European Ecommerce Report 2019' (2019)

<https://www.ecommercewiki.org/reports/614/european-ecommerce-report-2018>.

${ }^{10}$ Muller and others (n 5).

${ }^{11}$ Balcerowicz and others (n 4); Eurostat, 'European Economic Statistics 2010' (2011)

<http://ec.europa.eu/eurostat/documents/3217494/5730169/KS-GK-10-001-EN.PDF/71e6dd67-1ec9-4036-8a73-

419a000bfeb8?version=1.0>.

${ }^{12}$ OECD, ‘Turkey: OECD Economic Surveys' [2018] OECD Economic Surveys.

${ }^{13}$ Nordea, 'Foreign Trade Figures of Taiwan - Economic and Political Overview' (2020)

<https://www.nordeatrade.com/en/explore-new-market/taiwan/trade-profile>.

${ }^{14}$ Nordea, 'The Economic Context of Turkey - Economic and Political Overview' (Nordea Trade, 2020)

<https://www.nordeatrade.com/dk/explore-new-market/south-korea/economical-context>.

${ }^{15}$ Shatha Khalil, 'E-Commerce Creates a Change in the Global Economy' (2018).

${ }^{16}$ Lone and others (n 11).

${ }^{17}$ Melisande Cardona and others, 'The Macro-Economic Impact of e-Commerce in the EU Digital Single Market' (2015).
} 


\subsection{Economic Growth comparison across EU-15, EU-27 and Turkey with reference to Ecommerce market}

With the constant rise in internet penetration in Europe from $77.63 \%$ in 2015 to $83.11 \%$ in 2018, there has been shift in consumer and business preferences towards the ecommerce market.

Eurostat report of 2018 states that about $62.6 \%$ of the shoppers in EU-15, 55.23\% in EU-27 and 53\% in Turkey have made online purchase. In all the European countries i.e. EU-15, EU-27 and Turkey, clothes, sports, and travel were most popular goods or services for which ecommerce has been used ${ }^{18}$.Further, the E-GDP comparison among the regions shows that being the regions having fastest growth of ecommerce, EU-15 also had the highest contribution of it in GDP with 3.07\% E-GDP followed by Turkey with 2.09\% and EU-27 with 1.32\% in 2019.Even for the period 2013-2017, ecommerce sales increased by largest amount for Turkey with $943.93 \%, 230.45 \%$ for EU-27 and 226.9\% for EU-15. Thus, comparison of EU-15, EU-27 and Turkey shows that the highest development in the ecommerce is currently in EU-15 region but the pace of ecommerce growth in higher in Turkey and EU-27 region ${ }^{19}$.

\subsection{Empirical Review}

Simun $\mathrm{Liu}^{20}$ examined the impact of ecommerce on the economic growth of China by considering number of internet users, $\mathrm{CN}$ domain name, number of online shopping users, number of websites, scale of online advertising, and number of international outlet bandwidth as independent variables influencing the GDP or economic growth of country. The analysis depicts that there is significant influence of each of the factor on the economic growth and in order to enable development of economy, infrastructure of ecommerce system need to be improved. Falk and Hagsten $^{21}$ examined the contribution of ecommerce activities for 14 European countries for 2002-2010. Their analysis showed that over time there has been an increase in e-sales level and this increase leads to improvement in labor productivity with major contribution towards the smaller firms' growth.

Anvari and Norouzi ${ }^{22}$ examined the 21 countries' ecommerce market by considering internet purchase by individuals, R\&D expenditure, health expenditure, and government size based on general government final consumption as independent variables. The analysis stated that $\mathrm{R} \& \mathrm{D}$ and ecommerce has a strong positive influence on economic growth with ecommerce having the stronger development enhancing effect. Anuj et. $\mathrm{al}^{23}$ further assessed the impact of ecommerce in Indian economy by revealing that ecommerce not only development infrastructure but also employment which together leads to social and economic growth of a country.

\subsection{Conceptual Framework}

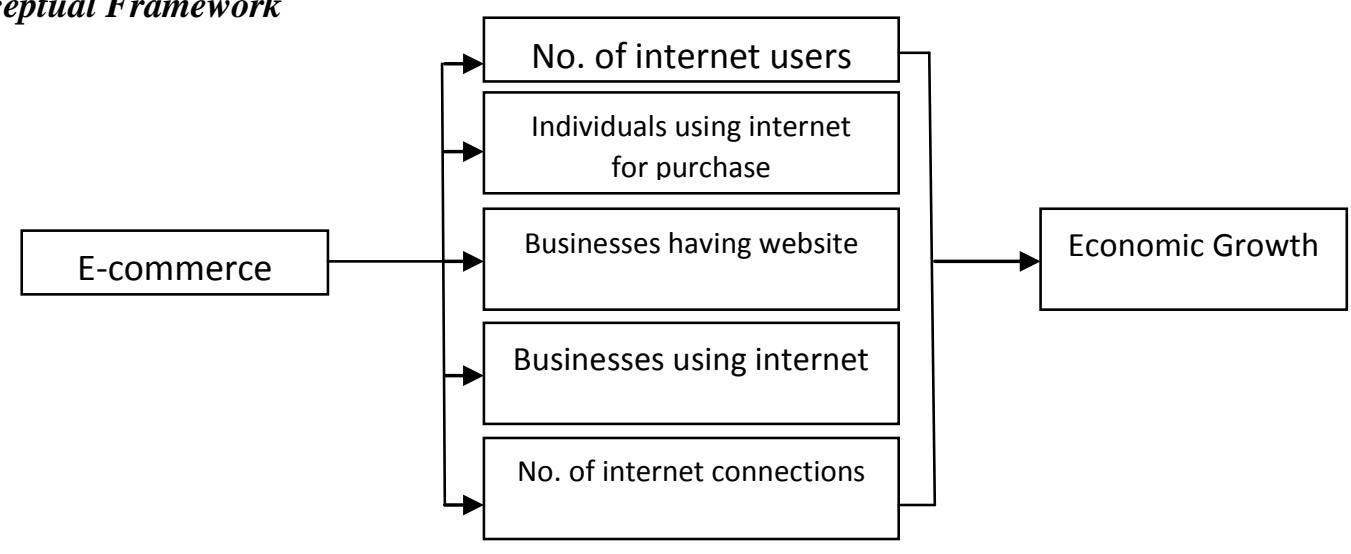

Figure 1: Conceptual Framework of the study

\footnotetext{
${ }^{18}$ Sara Lone, Adlen Khelladi and Shaun Packiarajah, 'European Ecommerce Report 2018 Edition' (2018); UNCTAD, 'Unlocking the Potential of E-Commerce for Developing Countries' (2015).

${ }^{19}$ Lone and others (n 11).

${ }^{20}$ Sixun Liu, 'An Empirical Study on E-Commerce's Effects on Economic Growth' [2013] International Conference on Education Technology and Management Science (ICETMS 2013) 0081.

${ }^{21}$ Martin Falk and Eva Hagsten, 'E-Commerce Trends and Impacts across Europe' (2015) 170 International Journal of Production Economics 357.

${ }^{22}$ Rana Deljavan Anvari and Davoud Norouzi, 'The Impact of E-Commerce and R\&D on Economic Development in Some Selected Countries' (2016) 229 Procedia - Social and Behavioral Sciences 354

<http://dx.doi.org/10.1016/j.sbspro.2016.07.146>.

${ }^{23}$ Kumar Anuj, Fahad Fayaz and Ms Namita Kapoor, 'Impact of E-Commerce in Indian Economy' (2018) 20 IOSR Journal of Business and Management (IOSR-JBM) 59.
} 
Based on the aim of the study to determine the contribution of ecommerce market in the economic growth of EU15, EU-27, and Turkey, the conceptual framework is framed. Herein, figure 1 show that ecommerce market status is determined by examining the number of internet users, individuals using internet for purchase, businesses having website, businesses using internet and no. of internet connection. Thus, each of the aspect impact is examined empirically in the economic growth or GDP of the region i.e. EU-15, EU-27, and Turkey.

\section{Methodology}

The examination of the trends of ecommerce market and economic growth was performed using the dataset for variables like exports of goods and services (annual \% growth), fixed broadband subscriptions (per 100 people), foreign direct investment, net inflows (\% of GDP),GDP growth (annual \%), imports of goods and services (annual $\%$ growth), individuals using the Internet (\% of population), individuals who purchased online - last $12 \mathrm{~m}(\%)$, businesses with a broadband connection -includes both fixed and mobile (\%), households with internet access at home (\%), households with broadband internet access at home (\%), and businesses with a website or home page (\%). The datawas collected from reliable secondary sources i.e. OECD, UNCTAD, and World development indicators for the period 2005-2019 online. In the first stage, trend analysis was performed on some variables, from which the changes in the ecommerce market status of each of the region were further analyzed. Further, for understanding the contribution of ecommerce market in economic growth, below stated hypothesis was tested.

$\mathrm{H}_{0}$ : There is no significant contribution of ecommerce in influencing the economic growth of the region.

$\mathrm{H}_{\mathrm{A}}$ : There is no significant contribution of ecommerce in influencing the economic growth of the region.

The above hypothesis was tested at $10 \%$ level of significance with Stata software. Comparison was drawn between the performance of EU-15, EU-27, and Turkey region.

\section{Data Analysis}

\subsection{Trend Assessment}

The trend analysis of the EU-15, EU-27, and Turkey assess the change in the ecommerce market level. Herein, comparison of the economic growth of the country with the individuals using internet would be done followed by having the examination of the businesses and household accessing internet. Analysis of each of the region is shown in below sub-sections.

\subsubsection{EU-15}

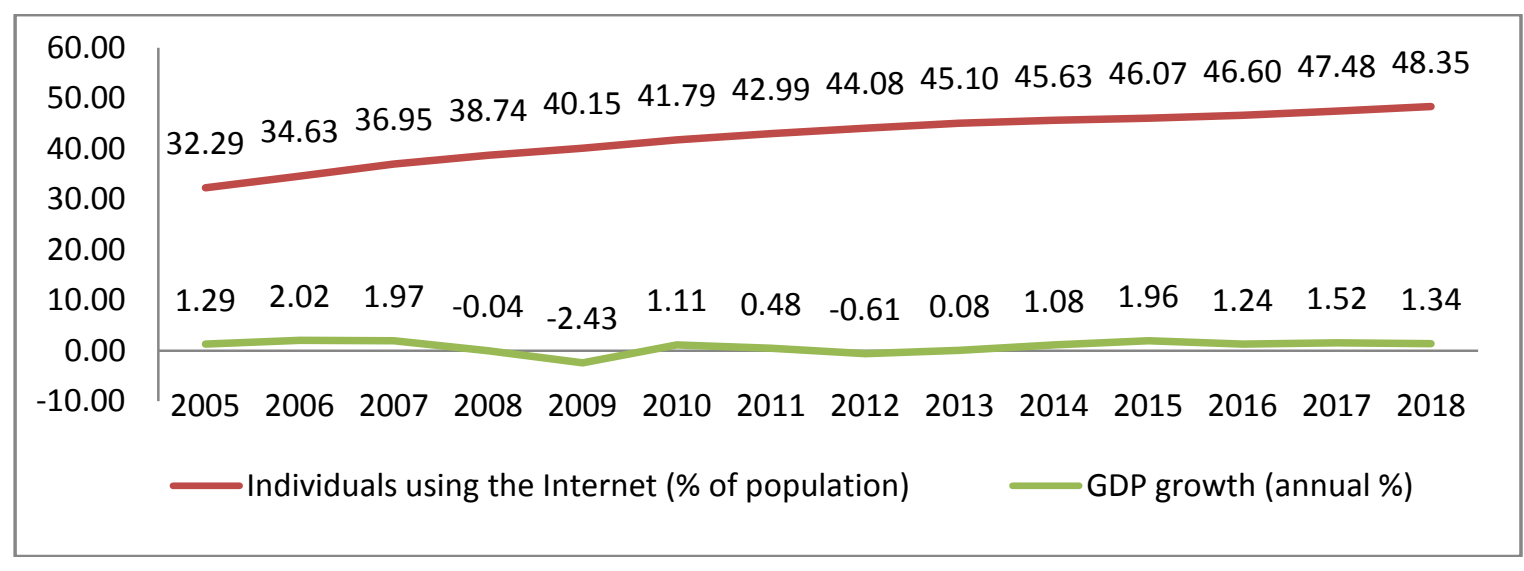

Figure 2: Trend analysis of Economic growth with internet usage for EU-15

Above figure shows that there has been variation in the economic status of the country with having the GDP growth rate as $1.29 \%$ in 2005 which increased to $2.02 \%$ in 2006 but due to global financial crisis reduced to $-2.43 \%$. Further, having the improvement in the financial condition of the countries and shift in focus towards business improvement, the economy began to improve with slight variation i.e. $1.96 \%$ in 2015 and $1.34 \%$ in 2018 .Further, the individuals using internet shows that with time as the economy is shifting towards having more of technology based working, the share in population has increased from $32.29 \%$ in 2005 to $48.35 \%$ in 2018. 


\begin{tabular}{|c|c|c|c|c|c|}
\hline 60.00 & 47.08 & 48.36 & 49.27 & 49.66 & 50.62 \\
\hline 40.00 & 44.16 & 44.83 & 44.76 & 45.36 & 41.61 \\
\hline \multicolumn{6}{|l|}{20.00} \\
\hline \multicolumn{4}{|l|}{0.00} & 2018 & 2019 \\
\hline & & esses & ebsite & e page & \\
\hline
\end{tabular}

Figure 3: Trend analysis of Internet access in EU-15 region

Figure 3 shows that during the period 2015-2019, the access of internet by households is continuously increasing i.e. from $47.08 \%$ in 2015 to $50.62 \%$ in 2019 ; however the pace of growth decreased initially i.e. $0.91 \%$ between 2016-2017 and 0.39\% between 2017-2018 but increased back during the period 2018-2019 i.e. 0.96\%. Further, businesses with a website or homepage showed that in EU-15 region, as the usage of technology is increasing, businesses are opting towards having more usage of internet i.e. increased from $44.16 \%$ in 2015 to $45.36 \%$ in 2018 but during 2019 , the rate fell to $41.61 \%$.

\subsubsection{EU-27}

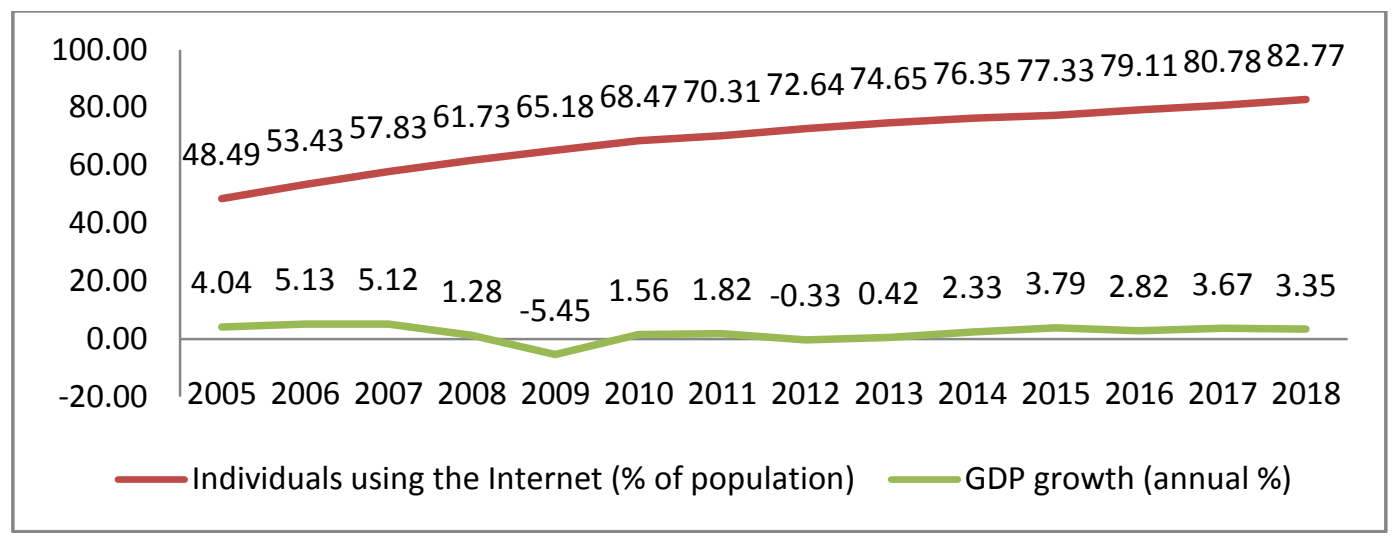

Figure 4: Trend analysis of Economic growth with internet usage for EU-27

Above figure shows the economic growth and internet access for EU-27 region wherein, majorly the economy was moving towards growth i.e. GDP growth rate increased from $4.04 \%$ in 2005 to $5.12 \%$ in 2007 but due to global financial crisis the rate fell to $-5.45 \%$ in 2009 . Having the shift in focus towards business improvement and overcoming the financial crisis condition by promoting foreign investment and having rise in manufacturing output and productivity; the growth rate rose back to $3.67 \%$ in 2017 . However, the internet usage by individuals is conditionally and was not affected by the financial crisis of the economy and degrading performance i.e. having rise from $48.49 \%$ of population in 2005 to $82.77 \%$ of population in 2018 .

\begin{tabular}{|c|c|c|c|c|c|}
\hline \multirow{7}{*}{$\begin{array}{r}100.00 \\
80.00 \\
60.00 \\
40.00 \\
20.00 \\
0.00\end{array}$} & \multirow{2}{*}{$\begin{array}{r}79.22 \\
72.32\end{array}$} & 81.92 & 83.38 & 85.29 & 86.93 \\
\hline & & 73.93 & 73.74 & 74.04 & 74.51 \\
\hline & & & & & \\
\hline & & & & & \\
\hline & 2015 & 2016 & 2017 & 2018 & 2019 \\
\hline & \multicolumn{5}{|c|}{ Businesses with a website or home page (\%) } \\
\hline & \multicolumn{5}{|c|}{ Households with Internet access at home (\%) } \\
\hline
\end{tabular}

Figure 5: Trend analysis of Internet access in EU-27 region 
Figure 5 shows that the rise in households having internet access is more than the business having usage of ICT via websites. During the period 2015-2019, the internet access of households has increased from $79.22 \%$ to $86.93 \%$ and the pace of growth was $2.7 \%, 1.46 \%, 1.91 \%$, and $1.64 \%$ respectively showing presence of increasing trend. Further, usage of website by businesses has increased from $72.32 \%$ to $74.51 \%$ in presence of variability in pace of growth i.e. increase to $73.93 \%$ followed by slight decrease $73.74 \%$ and increase to $74.51 \%$ in 2019 .

\subsubsection{Turkey}

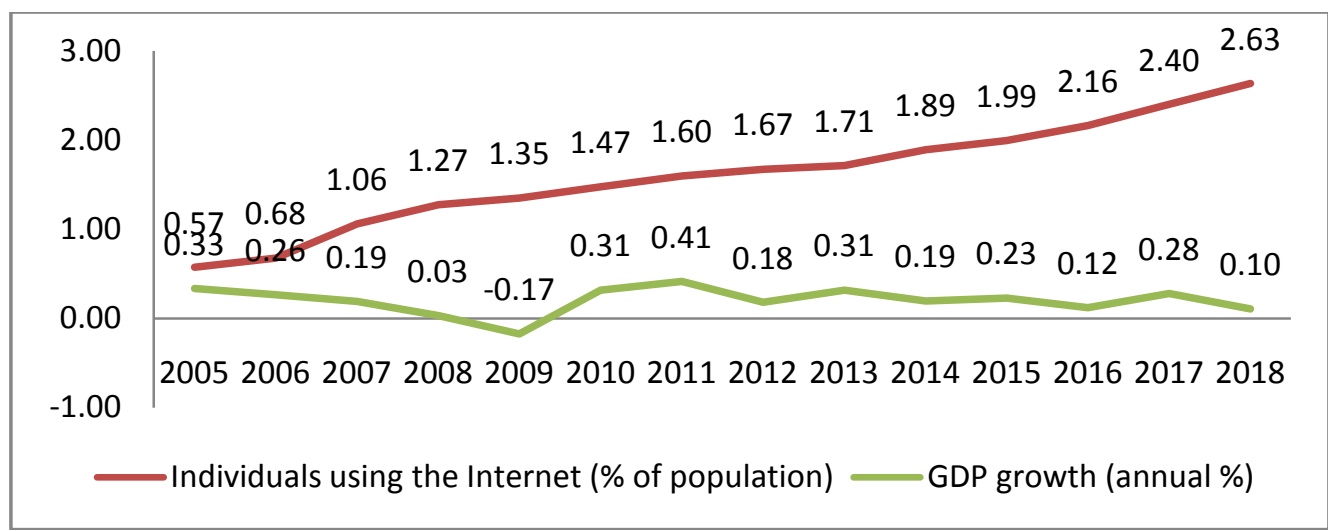

Figure 6: Trend analysis of Economic growth with internet usage for Turkey

Figure 6 shows the variation in economic growth and internet access of the individuals. With the existence of political instability, foreign issues, and financial crisis, Turkey witnessed the decreasing GDP growth rate with reduction in rate from $0.33 \%$ to $0.19 \%$ in 2007 followed by global financial crisis impact leading to fell in GDP growth rate to $-0.17 \%$. Further, with usage of expansionary monetary policies, and promotion of medium size firm emergence, the growth rate has increased with fluctuation due to high inflation rate and external imbalance leading to growth rate $0.28 \%$ in 2017 . However, individual access of internet shows that there is a rapid rise in the shift of internet towards internet usage leading to rise in population using internet share from $0.57 \%$ in 2005 to $2.63 \%$ in 2018.

\begin{tabular}{|c|c|c|c|c|c|}
\hline \multirow{2}{*}{$\begin{array}{l}4.00 \\
3.00 \\
2.00 \\
1.00 \\
0.00\end{array}$} & 2.58 & 2.83 & 2.99 & 3.10 & 3.27 \\
\hline & $2 . \overline{43}$ & 2.44 & 2.70 & 2.45 & 1.91 \\
\hline & 2015 & 2016 & 2017 & 2018 & 2019 \\
\hline & \multicolumn{5}{|c|}{ —Businesses with a website or home page (\%) } \\
\hline
\end{tabular}

Figure 7: Trend analysis of Internet access in Turkey region

Above figure shows that during 2015-2019, the internet access of households has increased from $2.58 \%$ to $3.27 \%$ however, the pace of growth has initially decreased and rose back in 2019 i.e. $0.25 \%, 0.16 \%, 0.11 \%$, and $0.17 \%$ respectively. Further, the businesses with website share has increased initially from $2.43 \%$ in 2015 to $2.70 \%$ in 2017 but later on with issues of lack of labor utilization, high unemployment, and decreased in foreign investment inflows, the share has decreased to $1.91 \%$ in 2019.

\section{Quantitative analysis}

The quantitative analysis focuses on statistical examination of the ecommerce market and economic growth in EU15, EU-27, and Turkey. Herein, the assessment of the nature of each variable, the contribution of ecommerce market in economic growth is determined by considering GDP growth rate as dependent variable (GDP) and individuals using internet (IntU), individuals who purchase online (IntPO), businesses with website or homepage (BW), businesses with broadband connection (BBS), and fixed broadband subscriptions (FBS) as independent variables in presence of various other control variables like foreign direct investment net inflows (FDI) and trade balance (TB). 


\subsection{EU-15}

\begin{tabular}{|l|l|l|l|}
\hline Variables & Test statistic & p-value & Optimal AIC lag \\
\hline GDP & -2.59 & 0.09 & 2 \\
\hline FDI & -0.88 & 0.80 & \\
\hline D.FDI & -3.54 & 0.01 & \\
\hline TB & -2.10 & 0.24 & \\
\hline D.TB & -2.99 & 0.04 & \\
\hline IntU & -1.49 & 0.54 & \\
\hline D.IntU & 0.54 & 0.99 & \\
\hline D.DIntU & -0.50 & 0.89 & \\
\hline IntU_01 & -2.41 & 0.14 & \\
\hline IntU_02 & -3.34 & 0.01 & \\
\hline IntPO & -3.61 & 0.01 & \\
\hline BW & -1.67 & 0.45 & \\
\hline D.BW & -3.52 & 0.01 & \\
\hline BBS & -1.41 & 0.58 & \\
\hline D.BBS & -3.27 & 0.02 & \\
\hline FBS & -1.71 & 0.43 & \\
\hline D.FBS & 0.67 & 0.99 & \\
\hline D.DFBS & -0.37 & 0.92 & \\
\hline FBS_01 & -1.44 & 0.56 & \\
\hline FBS_01 & -1.54 & 0.51 & \\
\hline D.FBS_01 & 0.66 & 0.99 & \\
\hline
\end{tabular}

Table 1: Stationary test for EU-15

Above table shows that the optimal lag as per AIC for all the variables is 2 . The p-value of adjusted dickey fuller test for GDP is 0.09 which is less than significance level of study i.e. 0.10 , thus null hypothesis of having unit root is rejected and GDP is stationary. Further, for IntPO p-value is $0.01<0.10$ representing its stationary nature while for FDI, TB, IntU, BW, BBS, and FBS p-value is greater than significance level i.e. 0.80, 0.24, 0.54, 0.45, 0.58, and $0.43>0.10$. Thus, first differentiation for variables is done and the $\mathrm{p}$-value for first differentiation shows that D.FDI, D.TB, D.BW, and D.BBS are less than significance level i.e. $0.01,0.04,0.01$, and $0.02<0.10$ and even 0.05 . Hence, FDI, TB, BW, and BBS have attained stationary nature. Further, as IntU and FBS is still nonstationary, second differentiation for the variable is done but as still $\mathrm{p}$-value is greater than 0.10 , thus lag for the variable is determined. For IntU at $2^{\text {nd }}$ lag p-value is $0.01<0.10$ and even 0.05 while for FBS stationary form is not derived. Therefore, FBS is excluded from the model deriving contribution of ecommerce market on economic growth.

\begin{tabular}{|l|l|l|l|l|l|l|}
\hline GDP & Coefficient & $\mathrm{t}$-stat & $\mathrm{p}$ & $\mathrm{R}^{2}$ & $\begin{array}{l}\text { Adjusted } \\
\mathrm{R}^{2}\end{array}$ & $\mathrm{~F}$ \\
\hline Constant & 12.38 & 1.51 & 0.18 & 0.73 & 0.45 & 2.65 \\
\hline D.FDI & 0.13 & 0.59 & 0.58 & & & \\
\hline D.TB & 0.32 & 0.77 & 0.47 & & & \\
\hline IntU_02 & -0.74 & -1.53 & 0.18 & & & \\
\hline IntPO & 0.67 & 1.58 & 0.17 & & & \\
\hline D.BW & -0.10 & -3.05 & 0.02 & & & \\
\hline D.BBS & 0.00 & -0.01 & 0.99 & & & \\
\hline
\end{tabular}

Table 2: Regression results for EU-15

Table 2 shows that $\mathrm{R}^{2}$ and Adjusted $\mathrm{R}^{2}$ value of model is 0.73 and 0.45 wherein Adjusted $\mathrm{R}^{2}$ shows that only about $45 \%$ of variation in GDP growth rate is determined by inclusion of ecommerce market and control variables. Fvalue for the model is 2.65 which is greater than 1 , thus precision in the model has increased with inclusion of ecommerce market and control variables. 
Lastly the p-value test for the variables show that only D.BW has p-value less than significance level of study i.e. $0.02<0.10$ and even 0.05 , thus, the null hypothesis of having no significant contribution of ecommerce market in influencing economic growth of EU-15 is rejected. Coefficient value further shows that as there has been increase in businesses with website of homepage by $1 \%$, the GDP growth rate for the region would decrease by $0.10 \%$. Hence, rise in businesses using website or homepage contribute in degrading the economic growth of EU-15 region.

\subsubsection{EU-27}

\begin{tabular}{|l|l|l|l|}
\hline Variables & $\begin{array}{l}\text { Test } \\
\text { statistic }\end{array}$ & p-value & $\begin{array}{l}\text { Optimal } \\
\text { AIC lag }\end{array}$ \\
\hline GDP & -2.49 & 0.12 & 4 \\
\hline D.GDP & -3.92 & 0.00 & \\
\hline FDI & -1.30 & 0.63 & \\
\hline D.FDI & -4.73 & 0.00 & \\
\hline TB & -1.83 & 0.37 & \\
\hline D.TB & -3.41 & 0.01 & \\
\hline IntU & -1.57 & 0.50 & \\
\hline D.IntU & 0.49 & 0.98 & \\
\hline D.DIntU & -1.11 & 0.71 & \\
\hline IntU_01 & -2.88 & 0.05 & \\
\hline IntPO & -2.16 & 0.22 & \\
\hline D.IntPO & -4.13 & 0.00 & \\
\hline BW & -1.55 & 0.51 & \\
\hline D.BW & -3.57 & 0.01 & \\
\hline BBS & -1.40 & 0.58 & \\
\hline D.BBS & -3.27 & 0.02 & \\
\hline FBS & -1.73 & 0.42 & \\
\hline D.FBS & 0.73 & 0.99 & \\
\hline D.DFBS & -0.38 & 0.91 & \\
\hline FBS_01 & -1.50 & 0.53 & \\
\hline FBS_02 & -1.64 & 0.46 & \\
\hline FBS_03 & -1.79 & 0.39 & \\
\hline FBS_04 & -1.74 & 0.41 & \\
\hline
\end{tabular}

Table 3: Stationary test for EU-27

Table 3 shows that the optimal lag value for all the variables is 4 . With the p-value higher than the significance level of study for all the variables i.e. GDP-0.12, FDI-0.63, TB-0.37, IntU-0.50, IntPO-0.22, BW-0.51, BBS-0.58, and FBS-0.42; first differentiation was done. Herein, the first difference led to having p-value of D.GDP (0.00), D.FDI (0.00), D.TB (0.01), D.IntPO (0.00), D.BW (0.01), and D.BBS (0.02) less than the significance level of study i.e. 0.10 or even 0.05 . Thus, the null hypothesis of having unit root is rejected showing derivation of stationary nature. Further as D.IntU and D.FBS still has high p-value thus second differentiation was done but still p-value is high. Hence, lag transformation for the variable is done wherein for IntPO stationary form is derived at $1^{\text {st }}$ lag i.e. IntU_01 as 0.05 . As FBS even after 4 lag transformations does not have significant p-value and optimal lag permitted for first order differenced and second order difference FBS is 0 , thus it is excluded from the model. 


\begin{tabular}{|l|l|l|l|l|l|l|}
\hline D.GDP & Coefficient & t-stat & $\mathrm{P}$ & $\mathrm{R}^{2}$ & $\begin{array}{l}\text { Adjusted } \\
\mathrm{R}^{2}\end{array}$ & $\mathrm{~F}$ \\
\hline Constant & -3.60 & -1.09 & 0.31 & 0.88 & 0.78 & 8.47 \\
\hline D.FDI & -0.09 & -0.95 & 0.37 & & & \\
\hline D.TB & -1.74 & -4.01 & 0.01 & & & \\
\hline IntU_01 & 0.04 & 1.00 & 0.35 & & & \\
\hline D.IntPO & 0.05 & 0.77 & 0.47 & & & \\
\hline D.BW & 0.01 & 0.29 & 0.78 & & & \\
\hline D.BBS & 0.03 & 2.39 & 0.05 & & & \\
\hline
\end{tabular}

Table 4: Regression results for EU-27

The value of $\mathrm{R}^{2}$ and Adjusted $\mathrm{R}^{2}$ is 0.88 and 0.78 wherein adjusted $\mathrm{R}^{2}$ shows that about $78 \%$ of the variation in the GDP growth rate is determined by ecommerce and control variables. F-value further shows that as it is greater than the required value of 1 i.e. 8.47>1, thus more precision is derived in the model with inclusion of ecommerce market and control variables. Lastly, the p-value for D.TB and D.BBS is less than the significance level i.e. 0.01 and 0.05 $<0.10$, thus null hypothesis of having no significant contribution of ecommerce market in economic growth of EU27 region is rejected. Coefficient value shows that with businesses with broadband connection, the economic growth rate of EU region increases by $0.03 \%$. Further, with $1 \%$ increase in trade balance, the EU-27 growth rate decreases by $1.74 \%$. Hence, the development of ecommerce market in EU-27 region contributes in its economic growth.

\subsubsection{Turkey}

\begin{tabular}{|l|l|l|l|}
\hline Variables & $\begin{array}{l}\text { Test } \\
\text { statistic }\end{array}$ & p-value & $\begin{array}{l}\text { Optimal } \\
\text { AIC lag }\end{array}$ \\
\hline GDP & -2.93 & 0.04 & 3 \\
\hline FDI & -1.76 & 0.40 & \\
\hline D.FDI & -4.60 & 0.00 & \\
\hline TB & -3.93 & 0.00 & \\
\hline IntU & -2.00 & 0.29 & \\
\hline D.IntU & -1.19 & 0.68 & \\
\hline D.DIntU & -0.51 & 0.89 & \\
\hline IntU_01 & -2.05 & 0.27 & \\
\hline IntU_02 & -2.14 & 0.23 & \\
\hline IntU_03 & -1.82 & 0.37 & \\
\hline IntPO & 0.88 & 0.99 & \\
\hline D.IntPO & -5.00 & 0.00 & \\
\hline BW & -1.62 & 0.47 & \\
\hline D.BW & -4.47 & 0.00 & \\
\hline BBS & -2.50 & 0.11 & \\
\hline D.BBS & -4.25 & 0.00 & \\
\hline FBS & -2.14 & 0.23 & \\
\hline D.FBS & -0.98 & 0.76 & \\
\hline D.DFBS & -0.77 & 0.83 & \\
\hline FBS_01 & -2.55 & 0.10 & \\
\hline FBS_02 & -2.78 & 0.06 & \\
\hline & & & \\
\hline
\end{tabular}

Table 5: Stationary test for Turkey

Table 5 shows that the optimal AIC lag for all the variables is 3. For GDP and TB, the p-value is 0.04 and $0.00<$ 0.10 , thus GDP and TB is in stationary form. However, for FDI, IntU, IntPO, BW, BBS, and FBS p-value is higher than 0.10 i.e. $0.40,0.29,0.99,0.47,0.11$, and 0.23 . Thus, first order differentiation for the variables was done. The 
p-value for D.FDI, D.IntPO, D.BW, and D.BBS is derived to be less than significance level i.e. $0.00<0.10$ or even 0.05 .

Hence, stationary for all these variables is derived. As still IntU and FBS is non-stationary thus, second order differentiation for the variables was done but due to having higher p-value, lag transformation was done. Herein, $2^{\text {nd }}$ lag of FBS has derived the $\mathrm{p}$-value of $0.06<0.10$ but still IntU value is higher. Hence, IntU is excluded from the model stating relationship between ecommerce market and economic growth of Turkey.

\begin{tabular}{|l|l|l|l|l|l|l|}
\hline GDP & Coefficient & $\mathrm{t}$-stat & $\mathrm{p}$ & $\mathrm{R}^{2}$ & $\begin{array}{l}\text { Adjusted } \\
\mathrm{R}^{2}\end{array}$ & $\mathrm{~F}$ \\
\hline Constant & 0.24 & 4.01 & 0.01 & 0.91 & 0.82 & 10.15 \\
\hline D.FDI & 5.97 & 5.36 & 0.00 & & & \\
\hline TB & -0.31 & -4.32 & 0.01 & & & \\
\hline D.IntPO & 0.54 & 2.58 & 0.04 & & & \\
\hline D.BW & -0.09 & -2.11 & 0.08 & & & \\
\hline D.BBS & 0.02 & 0.92 & 0.39 & & & \\
\hline FBS_02 & 0.00 & -0.55 & 0.60 & & & \\
\hline
\end{tabular}

Table 6: Regression results for Turkey

Above table has R2 and Adjusted R2 value as 0.91 and 0.82 wherein Adjusted R2 shows that about $82 \%$ of the variation in GDP growth of turkey is determined by the ecommerce market and control variables. F-value of 10.15 is greater than the required value of 1 showing that precision in the model would be derived by including ecommerce market and control variables. Lastly, p-value for D.FDI, TB, D.IntPO, and D.BW is less than significance level of study i.e. $0.00,0.01,0.04$, and $0.08<0.10$, thus null hypothesis of having no significant contribution of ecommerce market in growth of turkey region is rejected. Coefficient value for ecommerce variable shows that with $1 \%$ increase in individual online purchase, economic growth rate increase by $0.54 \%$ while with $1 \%$ increase in businesses website, economic growth rate would decrease by $0.09 \%$. Further, the increase in FDI net inflows by $1 \%$ would raise the economic growth rate by $5.97 \%$ while rise in trade balance would degrade the economic growth rate by $0.31 \%$. Hence, rise in individual purchase online and FDI net inflows would improve the economic status of Turkey.

\section{Conclusion}

Ecommerce market being the source of connecting individuals and businesses on the online platform has boosted economic growth in many countries. Trend assessment showed that EU-27 had the highest growth in the internet usage and recovery from the financial crisis followed by EU-15 with slight low growth pace while Turkey with least growth rate. Access of the internet by household and businesses in form of website shows that EU-27 are more directed towards ecommerce market with more than $70 \%$ of the households and businesses using the internet, while the figure for EU-15 stood at $40 \%$. Turkey is the least developed in ecommerce market with only 2-3\% business and households engaging in online purchasing. Thus, with lower status of development currently in ecommerce market, Turkey has wider scope for growth of ecommerce, thus attracting FDI. EU-27 also shows promising growth potential in the future due to improved businesses broadband subscriptions, but EU-15 has lower development scope with ecommerce market due to market saturation. Thus, EU-27 has shown more developed status of ecommerce market while Turkey has more opportunity of availing benefits of ecommerce market in the future. Hence Turkey should focus on raising the confidence of foreign investors for increase in FDI inflows along with directing its investment towards promotion of internet based purchase by individuals.

Due to limited availability of data, this study empirically examined only EU-15, EU-27 and Turkey for 2005-2017 and with limited ecommerce variables. Future studies could be directed towards inclusion of some other aspects like ecommerce sales or ecommerce turnover and even having the comparison with the developed ecommerce market of US.

\section{References}

Abraham J and Lone S, 'European Ecommerce Report 2017' (2017)

Anuj K, Fayaz F and Kapoor MN, 'Impact of E-Commerce in Indian Economy' (2018) IOSR Journal of Business and Management (IOSR-JBM) 59

Anvari RD and Norouzi D, 'The Impact of E-Commerce and R\&D on Economic Development in Some Selected Countries' (2016) 229 Procedia - Social and Behavioral Sciences 354

<http://dx.doi.org/10.1016/j.sbspro.2016.07.146> 
Arguden Y, 'An Overview of the Turkish Economy: Outlook and Current Perspectives' [2007] The Middle East Institute Policy Brief

Balcerowicz L and others, 'Economic Growth in the European Union' [2013] Lisbon Council E-book 80

Cardona M and others, 'The Macro-Economic Impact of e-Commerce in the EU Digital Single Market' (2015)

CSR, 'The European Union: Questions and Answers' (2019)

Duch-Brown N and Martens B, 'The European Digital Single Market: Its Role in Economic Activity in the EU', vol 17 (2015) <https://ec.europa.eu/jrc/sites/jrcsh/files/JRC98723.pdf>

Eurostat, 'European Economic Statistics 2010' (2011) <http://ec.europa.eu/eurostat/documents/3217494/5730169/KS-GK-10-001-EN.PDF/71e6dd67-1ec94036-8a73-419a000bfeb8?version=1.0>

Falk M and Hagsten E, 'E-Commerce Trends and Impacts across Europe' (2015) 170 International Journal of Production Economics 357

Khalil S, 'E-Commerce Creates a Change in the Global Economy' (2018)

Liu S, 'An Empirical Study on E-Commerce's Effects on Economic Growth' [2013] International Conference on Education Technology and Management Science (ICETMS 2013) 0081

Lone S and others, 'European Ecommerce Report 2019' (2019)

<https://www.ecommercewiki.org/reports/614/european-ecommerce-report-2018>

Lone S, Khelladi A and Packiarajah S, 'European Ecommerce Report 2018 Edition' (2018)

Muller P and others, 'The EU Single Market: Impact on Member States' [2017] LE Europe 4

Nordea, 'Foreign Trade Figures of Taiwan - Economic and Political Overview' (2020) <https://www.nordeatrade.com/en/explore-new-market/taiwan/trade-profile>

- 'The Economic Context of Turkey - Economic and Political Overview' (Nordea Trade, 2020) <https://www.nordeatrade.com/dk/explore-new-market/south-korea/economical-context>

OECD, 'Turkey: OECD Economic Surveys' [2018] OECD Economic Surveys

Pamuk Ş, Economic Change in Twentieth-Century Turkey: Is the Glass More than Half Full? (2007)

Sansal B, 'Turkish Economy' (2020) <http://www.allaboutturkey.com/yagligures.htm>

UNCTAD, 'Unlocking the Potential of E-Commerce for Developing Countries' (2015)

US2EU, 'About the EU' (U.S. Mission to the European Union, 2020) 